\title{
Analysing economic contribution of tourism: insights from selected Southeast Asian countries
}

VU MINH HIEU, Ph.D., Van Lang University, Faculty of Commerce and Business

Administration,

Vietnam, ORCID: 0000-0001-9525-2013.

HUA THI BACH YEN, MSc., Ph.D. Student at Ho Chi Minh

Open University, Vietnam, ORCID: 0000-0001-8290-1715.

\section{Introduction}

Recently, the tourism industry has received attention across the world because of its contribution in stimulating consumption, promoting trade and international communication (Qian et al., 2018). Nowadays, the business volume of tourism is equals or more than the business volume of automobiles, food products and oil exports as it contributes $9 \%$ of GDP; $1 / 11$ direct, indirect and induced jobs; $6 \%$ of the World's exports i.e. US\$ 1.4 trillion in exports; $30 \%$ of the service exports (Robaina-Alves et al., 2016). Hitchcock et al. (2009) submitted that tourism has wide social, cultural, economic, political and environmental implications. Tourism is considered as one of the fastest growing and industries (Shahzad et al., 2017), that can facilitate economic recovery and growth if the potentials are properly managed. Additionally, tourism is one of the largest and most dynamic sectors that have significant effects on earnings, employment, foreign exchange and economic growth. It is recognized as a major contributor to economic growth and development in an emerging market (Haller, 2012; Shahzad et al., 2017). Arguably, 
tourism impacts many aspects of society, the same can be said of Southeast Asia tourism industry. The tourism sector in Southeast Asia has developed rapidly in recent years due to the free-market-oriented economy and foreign exchange earnings capability of the sector. Indeed, Southeast Asia is becoming a force to reckon in tourism development and destination. The upward trend in tourism arrivals in Southeast Asia shows the increased significance of tourism in the region. International tourists have acknowledged the attractiveness of tourism experiences in Southeast Asia in terms of rich cultural heritage and natural environment. In fact, these countries clearly recognize that tourism can be part of their development strategies, especially from an economic perspective (Barker, 2013). Sustainable tourism development involves different participants who determine and are impacted by development agenda. Scholars have examined tourism in different contexts such as Australia, Taiwan (Kim and Chen, 2006), Spain (Balaguer and Cantavella-Jorda (2002), Italy (Massidda and Etzo 2012), (Oh, 2005) Korea. This study focuses on the contribution of tourism to Gross domestic products, employment, investment and visitor exports in five southeast Asian countries (Indonesia, Malaysia, Singapore, Thailand and Vietnam). These countries were categorized as Southeast Asia most tourist-friendly destinations (World economic forum, 2017). Thus, justifying their selection for this study. Tourism contribution to total GDP represent activities that deal with tourists such as hotels, travel agents airlines, restaurants and leisure industries. Total employment represents jobs created directly and indirectly in the travel and tourism sector. Investment includes capital investment spending directly related to travel and tourism such as new visitors' accommodation, passenger transport equipment, restaurants and leisure facilities for tourism use (WTTC, 2018). Visitor exports refer to spending within the country by international tourists for business and leisure trips excluding spending on education. Specifically, the study assessed and compared the economic contribution of tourism in five Southeast Asian countries. Second, proposed recommendations to managers and policymakers based on the evaluation of the subject.

\section{Methodology}

Secondary data was used in this paper which was collected from world travel and tourism council database for the study. A dataset covering 10 year period from (2008 -2017) for Indonesia, Malaysia, Singapore, Thailand, and Vietnam were analysed. Data for tourism contribution to the Gross domestic product, employment investment and visitor exports were collected from World travel 
and tourism council database. the author used real prices in US\$ to access GDP, investment and visitor exports. Real prices are considered appropriate because it considers the effect of inflation. Employment was assessed base on the number of jobs created in the tourism sector. Descriptive statistics in form of charts, mean and standard deviation were used for analyzing the data.

\section{Tourism in Southeast Asia}

There are eleven counties in Southeast Asia, namely: Singapore, Malaysia, Thailand, Indonesia, Vietnam, Myanmar (Burma), Philippines, Lao PDR, Cambodia, Brunei and East Timor. The Southeast Asia tourism industry with its tourism potentials have witnessed fast growth and is estimated to continue to grow (Chheang, 2013). Southeast Asian governments are trying to exploit the tourism industry to earn foreign exchange and generate more jobs for their citizens. Most of the countries in Southeast Asia are using public-private sector partnerships to expand their tourism industry. World Travel and Tourism Council 2018 report ranked 13 regions based on the relative contribution of tourism to total GDP, employment, investment and visitor exports. In 2017, Southeast Asia was ranked $3^{\text {rd }}$ on the contribution of tourism to total GDP, $3^{\text {rd }}$ on employment,

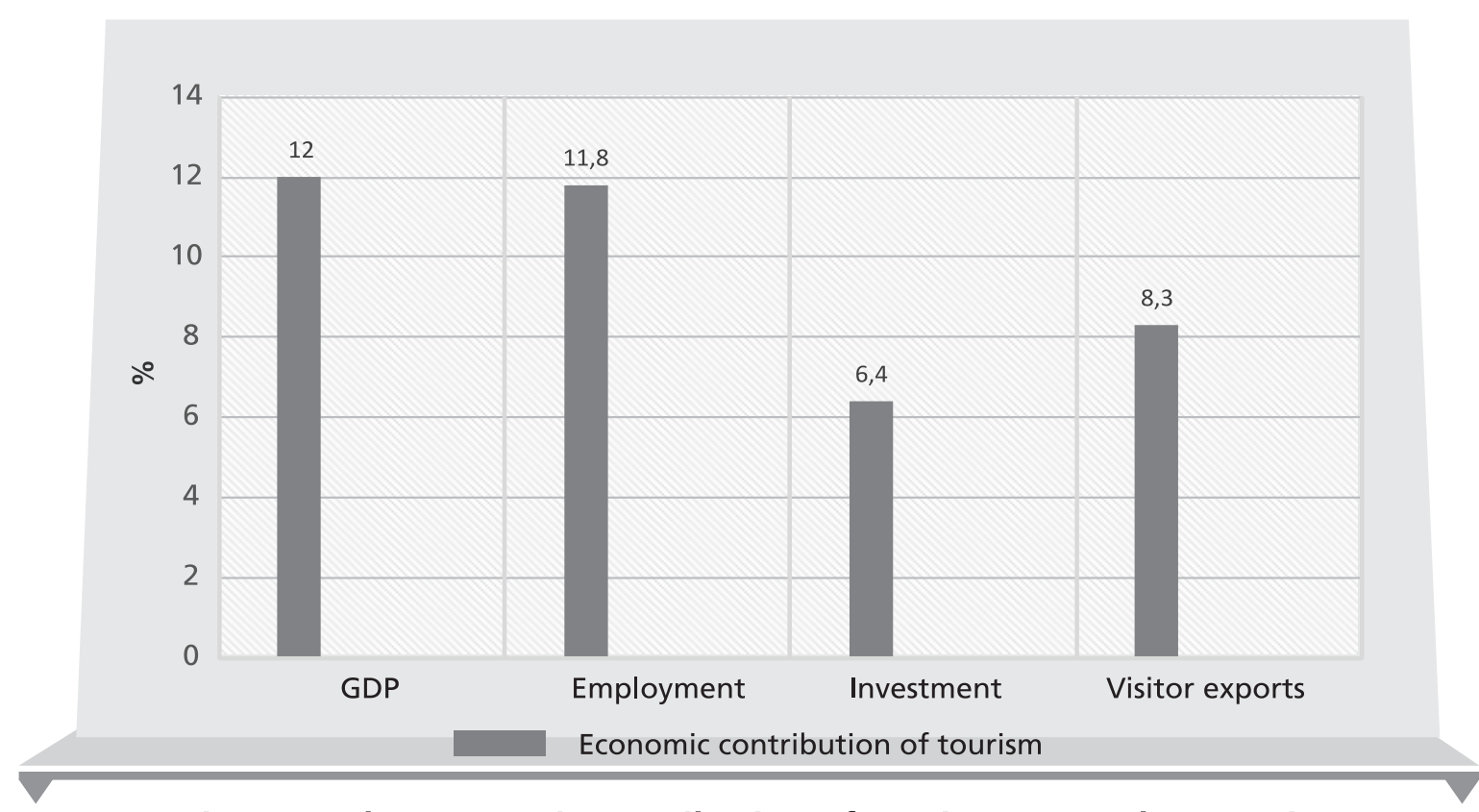

Figure 1. The economic contribution of tourism to Southeast Asia

Source: author adaptation of world travel and tourism council report 2018 
4th on investment and $6^{\text {th }}$ on visitor exports (World Travel and Tourism Council, 2018). The tourism share of Southeast Asia in terms of contribution to Gross Domestic Product (GDP), employment, investment and visitor exports is among the best compared to other regions. Figure 1 . show that tourism contributed 12 \% (\$329.5bn) to GDP, $11.8 \%$ to employment (36.3 million jobs), $6.4 \%$ (\$48.8bn) to investment and $8.3 \%$ (\$135.6bn) to visitor exports in 2017 (World Travel and Tourism Council, 2017).

The economic contribution of tourism in selected Southeast Asian countries. Statistical data available from the WTTC (2018) in figure 2, shows that tourism contribution to GDP (real prices) for Indonesia steadily rose from $\$ 38.9$ bn in 2008 to $\$ 55.8$ bn in 2017. A similar trend was observed in Malaysia, where the GDP (real prices) steadily increased from \$26.20bn in 2008 to $\$ 41.87 \mathrm{bn}$ in 2017. In Singapore, tourism contribution to GDP (real prices) was $\$ 18.48 \mathrm{bn}$ in 2008 , declined to $\$ 18.39 \mathrm{bn}$ in 2009 , increased from $\$ 23.53 \mathrm{bn}$ in 2010 to $\$ 31.48 \mathrm{bn}$ in 2017. Tourism contribution to GDP (real prices) in Vietnam experienced a sharp decline from $\$ 15.06 \mathrm{bn}$ in 2008 to $\$ 12.58 \mathrm{bn}$ in 2009 , followed by a rise from $\$ 14.5 \mathrm{bn}$ in 2010 to $\$ 20.61 \mathrm{bn}$ in 2017. In Thailand,

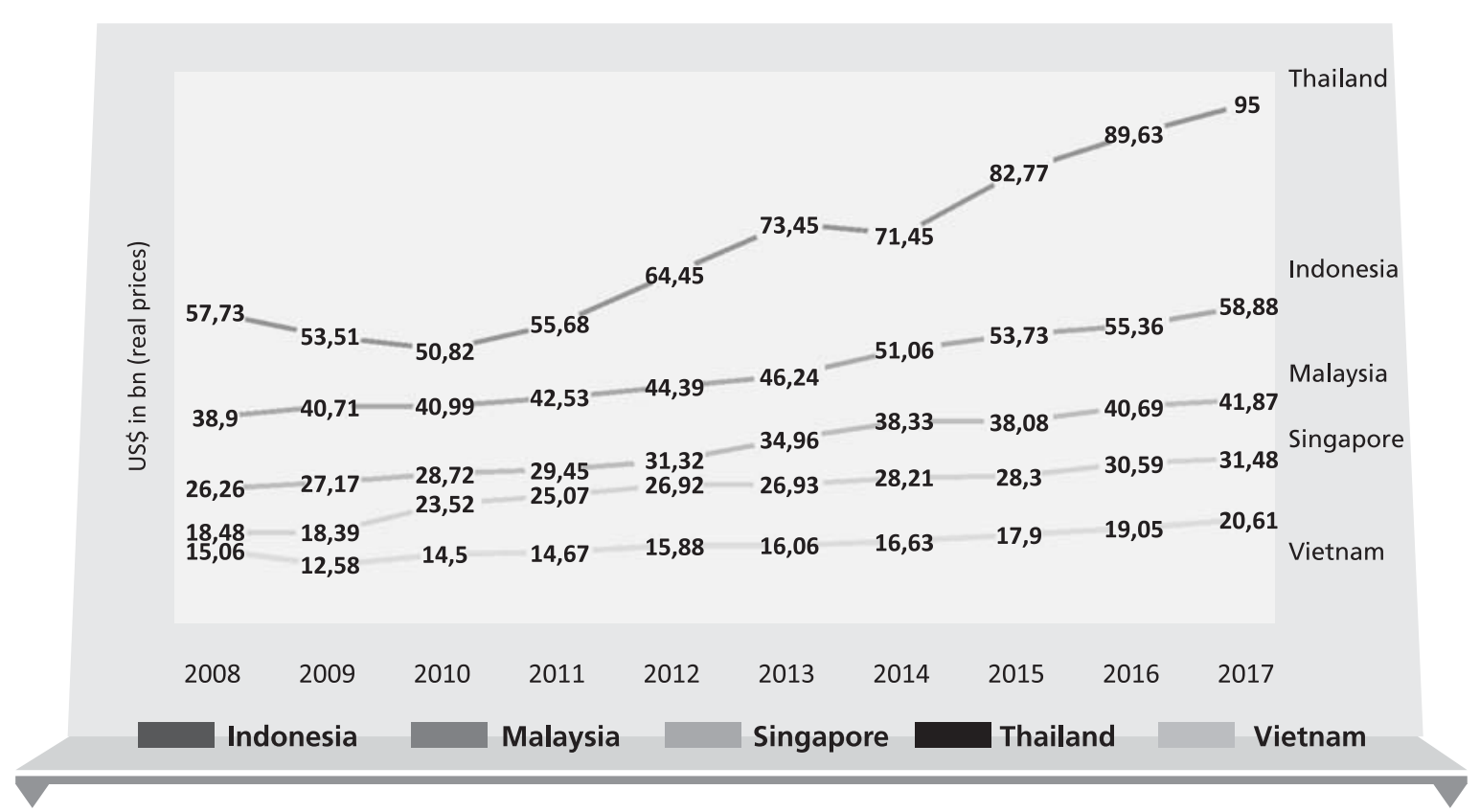

Figure 2. Tourism contribution to GDP of Indonesia, Malaysia, Singapore, Thailand and Vietnam

Source: world travel and tourism council data elaborated by author 
tourism contribution to GDP (real prices) declined from $\$ 57.73 \mathrm{bn}$ in 2008 to $\$ 53.51 \mathrm{bn}$ and $\$ 50.82 \mathrm{bn}$ in 2009 and 2010 , followed by a sharp rise from $\$ 55.68 \mathrm{bn}$ in 2011 to $\$ 73.45$ in 2013 and a decline to $\$ 71.45 \mathrm{bn}$ in 2014 . Thailand witnessed a steady rise in tourism contribution to GDP from $\$ 82.17 \mathrm{bn}$ in 2015 to $\$ 95 \mathrm{bn}$ in 2017. In the last ten years, Indonesia and Malaysia appear to have a consistent and upward movement in the contribution of tourism to their GDP. In 2009, other countries (Singapore, Vietnam, Thailand) had a decline in tourism contribution to GDP. This may be due to the negative impact of the global financial crisis.

Figure 3 , shows that tourism contribution to employment in Indonesia declined from 3570.82 in 2008 to 3123.29 in 2011, follow by a steady rise from 3201.27 in 2012 to 4585.9 in 2017. In Singapore, tourism contribution to employment experienced a sharp decline from 102.082 in 2008 to 85.0633 in 2009 followed by a consistent rise from 112.926 in 2010 to 169.284 in 2017. Tourism contribution to employment in Thailand witness a steady fall from 2122.72 in 2008 to 1807.11 in 2011, increased from 2184.77 in 2012 to 2476.56 in 2013, a sharp decline to 2007.9 in 2014 and followed by a rise from 2256.59 in 2015 to 2336.58 in 2017. In the case of Malaysia, Tourism contribution to employment increased from 551.879

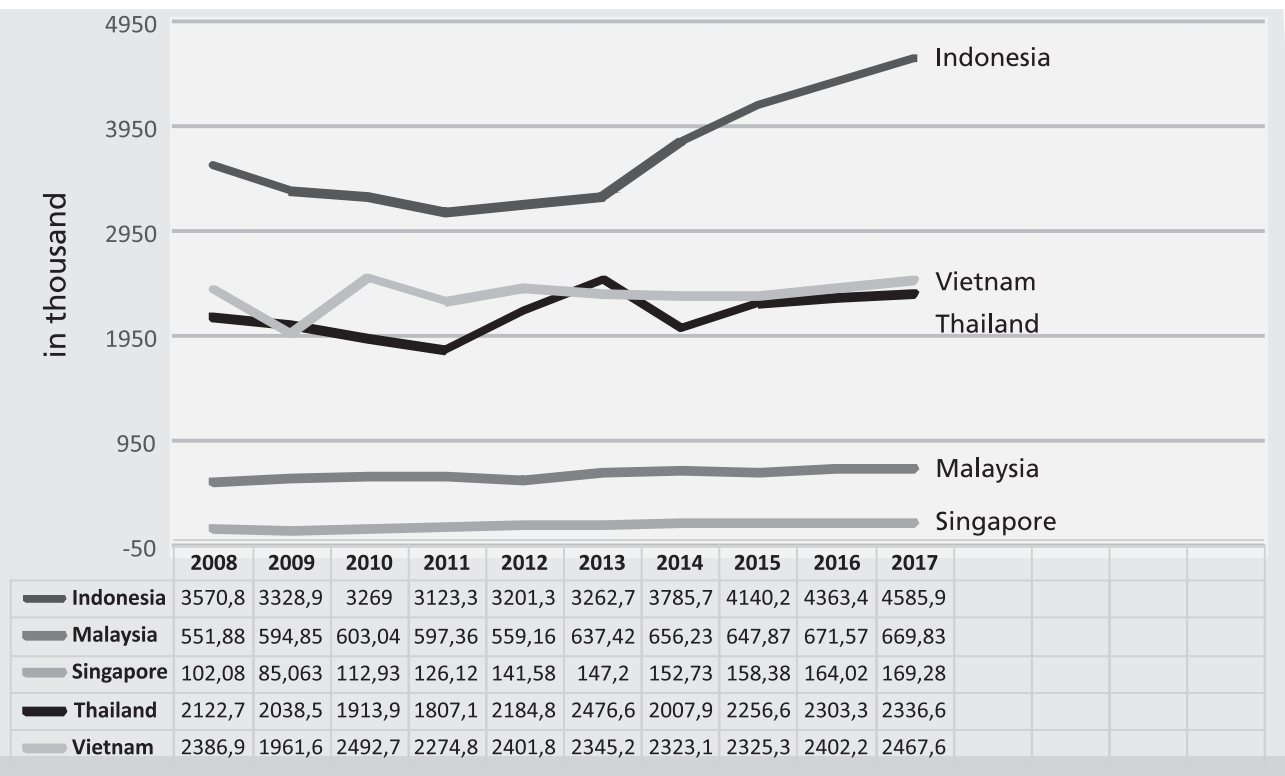

Figure 3. Tourism contribution to employment of Indonesia, Malaysia, Singapore, Thailand and Vietnam

Source: world travel and tourism council data elaborated by author 
in 2008 to 603.044 in 2010, followed by a decline 597.361 in 2011, 559.16 in 2012. Malaysia experience a steady rise in tourism contribution to employment from 637.422 in 2013 to 669.83 in 2017. Vietnam witness a sharp decline in tourism contribution to employment from 2386.85 in 2008 to 1961.58 in 2009, increased to 2492.67 in 2010, declined to 2274.82 in 2011, increased to 2401.84 in 2012, follow by a fall from 2345.17 in 2013 to 2323.11 in 2014, then rose from 2325.26 in 2015 to 2467.64 in 2017. In Vietnam, tourism contribution to employment is not steady and characterized by a high level of fluctuation. In the last ten years, tourism has consistently created more jobs in Indonesia compared to other Southeast Asian countries (Singapore, Vietnam, Thailand). From 2012 to 2015, Indonesia, Malaysia and Singapore experienced upward movement in the numbers of jobs created by the tourism sector.

Figure 4 shows that tourism contribution to investment (real prices) for Indonesia witness a sharp increase from $\$ 5.88 \mathrm{bn}$ in 2008 to $\$ 8.69 \mathrm{bn}$ in 2009, declined to $\$ 8.14 \mathrm{bn}$ in 2010, rose steadily from $\$ 9.13 \mathrm{bn}$ in 2011 to $\$ 11.71 \mathrm{bn}$ in 2015, declined to $\$ 11.61 \mathrm{bn}$ in 2016 and increased to $\$ 12.03 \mathrm{bn}$ in 2017. In Singapore, tourism contribution to investment (real prices) declined from $\$ 12.86 \mathrm{bn}$ in 2008 to $\$ 11.77 \mathrm{bn}$ in 2010, rose from $\$ 12.04 \mathrm{bn}$ in 2011 to $\$ 14.5 \mathrm{bn}$ in 2017. Tourism

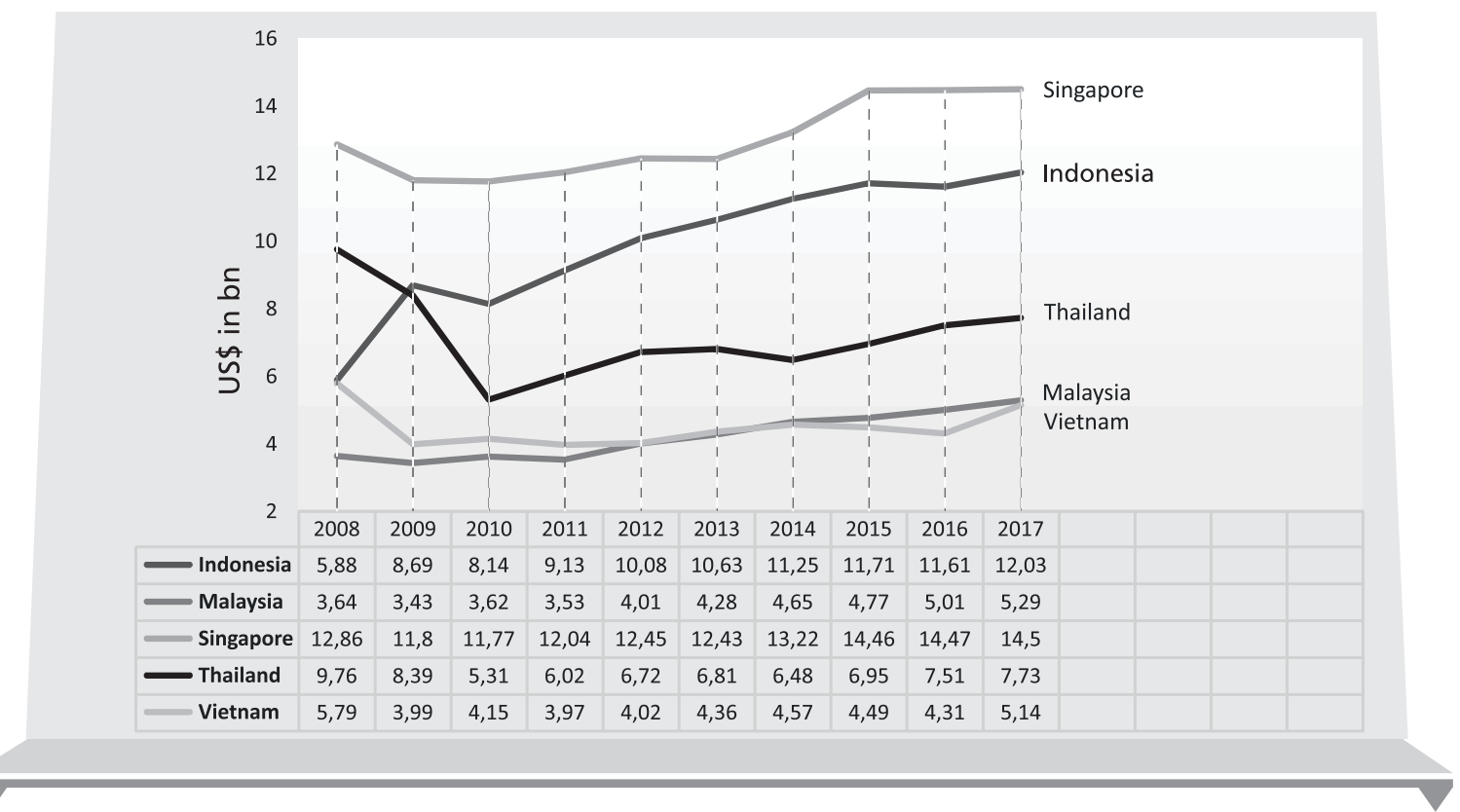

Figure 4. Tourism contribution to investment of Indonesia, Malaysia, Singapore, Thailand and Vietnam

Source: world travel and tourism council data elaborated by author

Analysing economic contribution of tourism: insights from selected Southeast Asian 
contribution to investment (real prices) in Thailand experienced sharp fall from $\$ 9.76 \mathrm{bn}$ in 2008 to $\$ 5.31 \mathrm{bn} 2010$, followed by a steady rise from $\$ 6.02 \mathrm{bn}$ in 2011 to $\$ 6.81$ in 2013, declined to $\$ 6.48 \mathrm{bn}$ in 2014, and increased from $\$ 6.95 \mathrm{bn}$ in 2015 to $\$ 7.73$ in 2017. In the case of Malaysia, tourism contribution to investment (real prices) declines from \$3.64bn in 2008 to \$3.43bn in 2009. In 2010 there was a marginal rise to $\$ 3.62 \mathrm{bn}$, followed by a decline to $\$ 3.53 \mathrm{bn}$ in 2011 and a steady rise from $\$ 4.01 \mathrm{bn}$ in 2012 to $\$ 5.29 \mathrm{bn}$ in 2017. In Vietnam, tourism contribution to investment (real prices) decline from \$5.79bn in 2008 to \$3.99bn in 2009, followed by a rise to $\$ 4.15 \mathrm{bn}$ in 2010 , and declined to $\$ 3.97 \mathrm{bn}$ in 2011 . There was a rise from $\$ 4.02 \mathrm{bn}$ in 2012 to $\$ 4.57 \mathrm{bn}$ in 2014, followed by a decline to $\$ 4.31 \mathrm{bn}$ in 2016, then rose to $\$ 5.14 \mathrm{bn}$ in 2017. Investments in the tourism sector in Singapore have experienced consistent expansion and upward trend. In the last six years (20122017), investment in the tourism sector is consistent with the upward trend in tourism contribution to employment in Indonesia, Malaysia and Singapore. This is expected as private and public sector invest in new visitors' accommodation, restaurants and leisure facilities more jobs are created.

Figure 5 shows tourism contribution to visitor exports (real prices) of sample countries. Indonesia experience sharp decline from \$9.15bn in 2008 to \$6.88bn in 2009 and steady rise from $\$ 7.08 \mathrm{bn}$ in 2010 to $\$ 14.41 \mathrm{bn}$ in 2017. In Singapore, tourism contribution to visitor exports (real prices) declined from $\$ 11.31 \mathrm{bn}$ in 2008 to $\$ 9.77 \mathrm{bn}$ in 2009, increased from \$14.23bn in 2011 to $\$ 17.54 \mathrm{bn}$ in 2014. In 2015, there was a sharp fall to $\$ 10.13 \mathrm{bn}$, followed by a sharp increase from $\$ 18.26 \mathrm{bn}$ in 2016 to $\$ 19.32$ in 2017. In the case of Thailand, tourism contribution to visitor exports (real prices) declined from $\$ 25.99 \mathrm{bn}$ in 2008 to $\$ 23.51 \mathrm{bn} 2009$, follow by a steady rise from $\$ 25.1 \mathrm{bn}$ in 2010 to $\$ 43.63$ in 2013, declined to $\$ 41.86 \mathrm{bn}$ in 2014, followed by a steady increase from $\$ 50.66$ bn in 2015 to $\$ 59.63$ in 2017. In Malaysia, tourism contribution to visitor exports (real prices) increased from $\$ 15.89 \mathrm{bn}$ in 2008 to $\$ 16.61 \mathrm{bn}$ in 2009 , declined from $\$ 16.57 \mathrm{bn}$ in 2010 to $\$ 15.84 \mathrm{bn}$ in 2011 , follow by a consistent rise from $\$ 16.24$ bn in 2012 to $\$ 18.66$ bn in 2014. In 2015, there was a decline to $\$ 17.33 \mathrm{bn}$, followed by a steady rise from $\$ 18.43 \mathrm{bn}$ in 2016 to $\$ 18.5 \mathrm{bn}$ in 2017. In Vietnam, tourism contribution to visitor exports (real prices) declined from $\$ 5.16 \mathrm{bn}$ in 2008 to $\$ 4.08 \mathrm{bn}$ in 2009 , followed by a rise from $\$ 5.73 \mathrm{bn}$ in 2010 to $\$ 7.24 \mathrm{bn}$ in 2013. In 2014, tourism contribution to visitor exports declined to $\$ 7.24 \mathrm{bn}$ and rose from $\$ 7.44 \mathrm{bn}$ in 2015 to $\$ 8.84 \mathrm{bn}$ in 2017. Thailand performed better in term of tourism contribution to visitor exports. This is evident with the consistent and upward movement in visitor exports from 2010 to 2017. This implies that spending by international tourists in Thailand has been growing steadily in the last 8 years. 


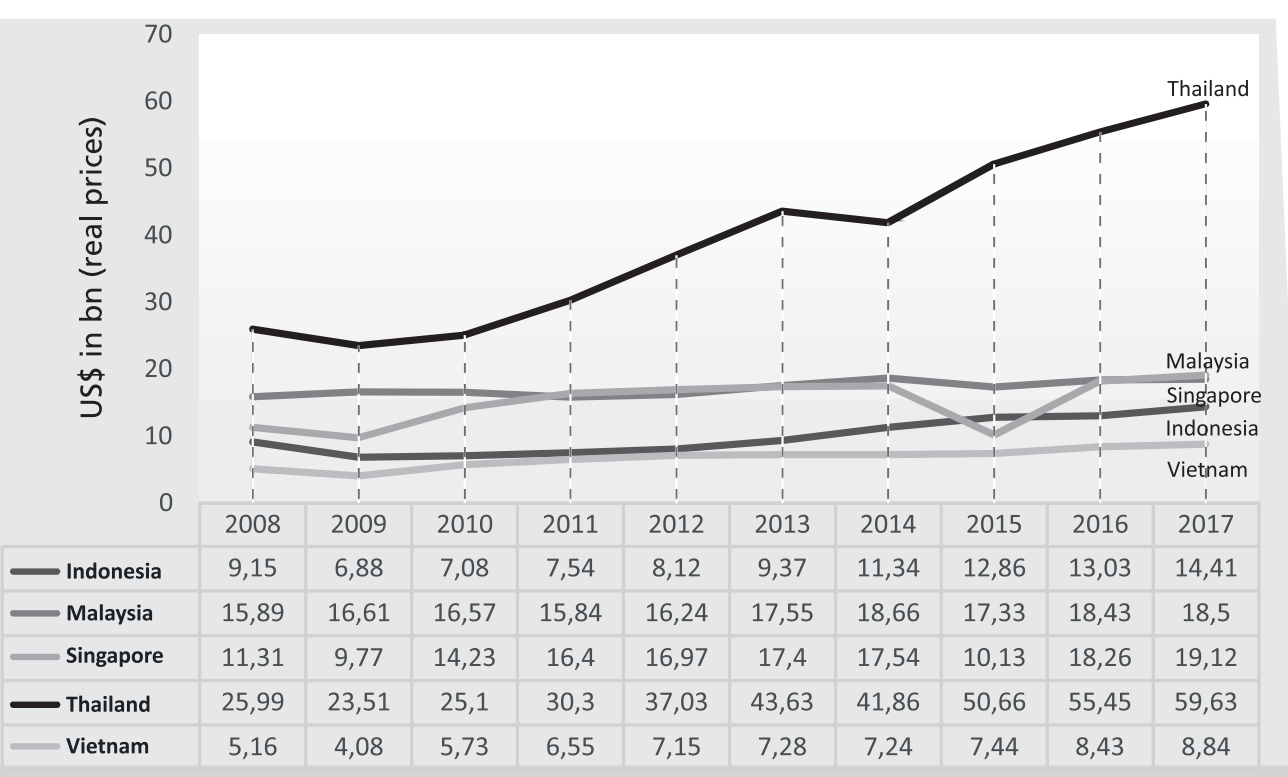

Figure 5. Tourism contribution to visitor exports of Indonesia, Malaysia, Singapore, Thailand and Vietnam

Source: world travel and tourism council data (2018) elaborated by author

\section{Descriptive statistics results}

Table 1. Descriptive statistics on economic contribution of tourism

\begin{tabular}{l|c|c|c|c|c|c|c|c|c|c}
\hline & \multicolumn{2}{|c|}{ Indonesia } & \multicolumn{2}{c|}{ Malaysia } & \multicolumn{2}{c|}{ Singapore } & \multicolumn{2}{c|}{ Thailand } & \multicolumn{2}{c}{ Vietnam } \\
\cline { 2 - 11 } & Mean & SD & Mean & SD & Mean & SD & Mean & SD & Mean & SD \\
\hline GDP & 47.2 & 6.99 & 33.7 & 5.82 & 25.8 & 4.52 & 69.5 & 15.7 & 16.3 & 2.36 \\
& & & & & & & & & & \\
\hline Employment & 3663 & 529.7 & 619 & 43.8 & 136 & 28.3 & 2145 & 206.5 & 2338 & 148.1 \\
\hline Investment & 9.92 & 1.96 & 4.22 & 0.67 & 13 & 1.11 & 7.17 & 1.26 & 4.48 & 0.58 \\
\hline Visitor exports & 9.98 & 2.74 & 17.2 & 1.09 & 15.1 & 3.51 & 39.3 & 13.09 & 6.79 & 1.48 \\
\hline $\mathrm{N}$ & 10 & 10 & 10 & 10 & 10 & 10 & 10 & 10 & 10 & 10 \\
\hline \hline
\end{tabular}

Source: own study, 2019 
Tab. 1 shows the overall mean and standard deviation of the contribution of tourism to GDP, employment, investment and visitor exports of Indonesia, Malaysia, Singapore, Thailand and Vietnam for 10 years. In Indonesia, the average GDP is $\$ 47.2 \mathrm{bn}, 3,663,000$ million jobs were created, investment $\$ 9.92 \mathrm{bn}$ and visitor exports is $\$ 9.98 \mathrm{bn}$ over the entire period from 2008 to 2017. The standard deviation of GDP is 6.99, employment is 529.7, investment is 1.96 and visitor exports is 2.74. In Malaysia the average GDP is $\$ 33.7 \mathrm{bn}, 619,000$ thousand jobs were created, investment is $\$ 4.22 \mathrm{bn}$ and visitor exports is $\$ 17.2 \mathrm{bn}$ over the entire period from 2008 to 2017. The standard deviation of GDP is 5.82, employment is 43.8, investment is 0.67 and visitor exports is 1.09. In Singapore, the average GDP is $\$ 25.8 \mathrm{bn}, 136,000$ thousand jobs were created, investment is $\$ 13 \mathrm{bn}$ and visitor exports is \$15.1bn over the entire period from 2008 to 2017. The standard deviation of GDP is 4.52, employment is 28.3, investment is 1.11 and visitor exports is 3.51. In Thailand, the average GDP is $\$ 69.5 \mathrm{bn}, 2,145,000$ million jobs were created, investment is $\$ 7.17 \mathrm{bn}$ and visitor exports is $\$ 39.3 \mathrm{bn}$ over the entire period from 2008 to 2017. The standard deviation of GDP is 15.7, employment is 206.5, investment is 1.26 and visitor exports is 13.09. In Vietnam, the average GDP is $\$ 16.9 \mathrm{bn}, 2,338,000$ million jobs were created, investment is $\$ 4.48 \mathrm{bn}$ and visitor exports is $\$ 6.79 \mathrm{bn}$ over the entire period from 2008 to 2017. The standard deviation of GDP is 2.36 , employment is 148.1, investment is 0.58 and visitor exports is 1.48 .

Table 2. The economic contribution of tourism ranking based on the mean (2008-2017)

\begin{tabular}{l|c|c|c|c|c}
\hline & Indonesia & Malaysia & Singapore & Thailand & Vietnam \\
\hline GDP & $2^{\text {nd }}$ & 3 rd & $4^{\text {th }}$ & $1^{\text {st }}$ & $5^{\text {th }}$ \\
\hline Employment & $1^{\text {st }}$ & $4^{\text {th }}$ & $5^{\text {th }}$ & $3^{\text {rd }}$ & 2 nd \\
\hline Investment & $2^{\text {nd }}$ & 5 th & 1 st & 3 rd & 4 th \\
\hline Visitor exports & 4 th & 2 nd & 3 rd & 1 st & 5 th \\
\hline overall score & 2.25 & 3.5 & 3.25 & 2 & 4 \\
\hline
\end{tabular}

Source: own study, 2019

Tab. 2. shows that Thailand is top in term of tourism contribution to GDP in real prices, $3^{\text {rd }}$ in employment and investment and $1^{\text {st }}$ in visitor exports. On 
average Thailand attracted more international tourists for both business and leisure compared to Indonesia, Singapore, Malaysia and Vietnam during the period (2008-2017). Vietnam was ranked 5th in term of tourism contribution to GDP and visitor exports, $2^{\text {nd }}$ on employment and $4^{\text {th }}$ on investment. Thus, Vietnam attracted the least international tourists during the period under review. However, Vietnam seems to be doing well with respect to the average number of jobs created in the travel and tourism sector. Indonesia outperformed other countries in term of the average numbers of jobs created in period 2008-2017. Indonesia is ranked $2^{\text {nd }}$ on GDP and investment and $4^{\text {th }}$ on visitor exports. Singapore created the least numbers of jobs during (2008-2017) the period under review. In term of average capital investment spending in the travel and tourism sector, Singapore performed better than the other countries. This implies that Singapore has invested more in specific assets for tourism use. Malaysia is ranked $3^{\text {rd }}$ on tourism contribution to GDP, $4^{\text {th }}$ on employment and $2^{\text {nd }}$ in visitor exports. Malaysia had the least capital investment spending in the travel and tourism sector over the period (20082017). The overall score is derived by finding the average of the ranked score. The least overall score is considered the best score. Thailand with an overall score (2) appears to out-performed other countries over the period (20082017). This implies that on the average (2008-2017) Thailand experienced more activities in the tourism sector compared to other sample countries. Indonesia with an overall score (2.25) is second, Singapore (3.25) is third, Malaysia (3.5) is fourth and Vietnam (4) is fifth.

Economic crises that happen in 2008-2010 affected the tourism is the sample countries. Also, the reason for differences could also be as a result of different tourism assets and environmental factors that are specific to the countries as shown in table 1. Also, most of the South East Asian countries have the catchups of the Chinese tourists, which help to increase and contribute to the economic development. Also, by the development of the economic conditions of those countries, the tourists among those countries and others have made up the travels. This is also a cause for tourism development. This is shown in the statistics of the UNWTO publication, "as in 2012 the Asean region was again featured as the fastest-growing globally, with a 10.8- percent increase in international tourist arrivals, a reflection of buoyant intra-regional demand" and "Brunei Darussalam received 225,000 international visitors; Cambodia 4.2 million; Indonesia 8.8 million; the Philippines 4.7 million; Vietnam 7.6 million; and Thailand 26.5 million" (UNWTO, 2014 cited in https://businessmirror.com.ph/2015/03/18/tourism-in-southeast-asia-is- 
growing-fast/) and as per statistics of the World Economic Forum, there are over 104 million international arrivals in 2015 and an average growth of $8 \%$, South-East Asia's travel which helped generate growth, create jobs and enable regional development (https://www.weforum.org/agenda/2017/04/ south-east-asia-s-most-tourism-friendly-destinations/). This is because the majority of nations in the region relying on their rich natural resources and ideal prices for tourists. They are also internationally open with visa policies. South East Asian States established the strategic role tourism plays in creating jobs and support the sector proactively although there is a large infrastructure (air, road, tourism service infrastructure) and the ICT readiness gap remains. At the same time, with security perceptions resulting from political developments in recent years, tourists come to South East Asian stability. In addition, South East Asia is recommended as the most tourismfriendly desitionations. (https://www.weforum.org/agenda/2017/04/southeast-asia-s-most-tourism-friendly-destinations/)

\section{Conclusion}

Tourism is one of the fastest growing sectors of most countries. Southeast Asian countries can use tourism to create employment opportunities and address economic problems facing them. They can improve their economic well-being by creating and sustaining strong partnerships, collaborations and sharing economic and physical infrastructures. The study analysed tourism contribution to GDP employment, investment and visitor exports in Indonesia, Malaysia, Singapore, Thailand and Vietnam. Based on author review and descriptive analyses of historical data, it was observed that tourism contribution to GDP is on the upward movement especially from the period 2013-2017. In term of numbers of job created, all the countries showed upward movement from 2014 to 2017. in the period 2014 to 2017, all the sample countries experienced consistent growth in investment, except Vietnam and Malaysia. In the period 2014-2017, spending by international tourists in Indonesia, Thailand and Vietnam grew. The results suggest that Thailand performed better than other sample countries in terms of tourism contribution to GDP, employment, investment and visitor exports. Thailand witnessed more activities in the travel and tourism sector as evident in tourism contribution to GDP and spending by international tourists (see table 1). It can be concluded, that Thailand is the top tourism destination in Southeast Asia. On the average, Vietnam appears to be the least performer 
in term of the economic contribution of tourism for the period 2008-2017. The study used secondary data and descriptive statistics to provide insights about the subject in five southeast Asian countries.

Despite the limitation described above, the study adds to tourism literature in the emerging market. Further studies can be done by using inferential statistics to access the relationship between tourism and economic indicators in all the southeast Asian countries. To achieve and sustain tourism development and economic growth in Southeast Asia, the author proposed the following recommendations:

1. Both public and private sectors should be actively involved in tourism development. Particularly, the government of Southeast Asia countries should provide robust infrastructure as this will foster growth in the tourism sector.

2. The government of Southeast Asian countries should establish and implement policies, rules and regulations that support the development of the tourism industry.

3. Governments of Southeast Asian countries need to create and sustain a favorable legal, socio-political environment, discourage exploitation, unfair competition, and unethical practices in the tourism sector.

4. The tourism businesses in Southeast Asian countries should provide quality services to tourists and good visitors' accommodation, passengers transport equipment, restaurants and leisure facilities.

5. A well planned and managed collaboration between the public and private sector is important to achieve sustainable growth in the tourism sector of southeast Asian countries.

6. The sample Southeast Asian countries should adopt robust tourism framework that will link institutions, organizations, decision-making rules and established practices.

The present study is limited to economic contribution of tourism to Southeast Asian countries. Future research should compare tourism contribution across regions.

\section{Summary}

Analysing economic contribution of tourism: insights from selected Southeast Asian countries

Tourism is a potential sector that can contribute positively to economic growth if properly managed. The southeast Asian 
countries have identified tourism as a key sector that can enable them to achieve sustainable economic growth. This study analysed the economic contribution of tourism in five southeast Asian countries (Indonesia, Malaysia, Singapore, Thailand and Vietnam). The paper aims to evaluate economic contribution of tourism in South Asiancountries by using secondary data covering 2008-2017 collected from world travel and tourism council database to draw insights about the subject. Descriptive statistics in form of tables, charts, mean and standard deviation were used for comparative analyses. Overall score indicated that Thailand is the best performer with respect to the economic contribution of tourism among the sample southeast Asian countries during the period 2008-2017. The study proposed six recommendations to managers and policymakers in the tourism sectors in Southeast Asia.

Keywords: Gross domestic product, employment, visitor exports, investment, Southeast Asia.

\section{Streszczenie}

Analiza wkładu gospodarczego turystyki: spostrzeżenia z wybranych krajów Azji Południowo-Wschodniej

Turystyka jest potencjalnym sektorem, który może pozytywnie przyczynić się do wzrostu gospodarczego, jeśli jest właściwie zarządzany. Kraje Azji Południowo-Wschodniej uznały turystykę za kluczowy sektor, który może umożliwić im osiągnięcie zrównoważonego wzrostu gospodarczego. W badaniu przeanalizowano ekonomiczny wkład turystyki w pięciu krajach Azji Południowo-Wschodniej (Indonezja, Malezja, Singapur, Tajlandia i Wietnam). Autor wykorzystał dane wtórne obejmujące lata 2008-2017 zebrane $\mathrm{z}$ bazy danych światowych rad ds. podróży i turystyki, aby uzyskać wgląd $w$ ten temat. Do analiz porównawczych wykorzystano statystyki opisowe w postaci tabel, wykresów, średniej i odchylenia standardowego. Ogólny wynik wskazał, że Tajlandia osiąga najlepsze wyniki pod względem wkładu gospodarczego turystyki wśród analizowanych krajów Azji Południowo-Wschodniej w latach 2008-2017. W badaniu zaproponowano sześć zaleceń menedżerom i decydentom w sektorach turystycznych w Azji Południowo-Wschodniej. 


\section{Słowa}

kluczowe: produkt krajowy brutto, zatrudnienie, eksport odwiedzajacych, inwestycje, Azja Południowo-Wschodnia.

JEL

Classification: M10, Z30

\section{References}

1. Baker, D.M.A (2013). Understanding the Economic Impact of Tourism in the Asian Pacific Region Using the Tourism Satellite Account (TSA). International Journal of Business and Social Science, 4(3),15-22.

2. Balaguer, J. \& Cantavella-Jorda, M. (2002). Tourism as a Long-Run Economic Growth Factor: The Spanish Case. Applied Economics, 34, 877884.

3. Chheang, V. (2013). Tourism and regional integration in Southeast Asia. Institute of Development Economies, 481, 1-93.

4. Haller, A. (2012). Growth and development through tourism in conditions of liberalization. Theories and concepts. Paper presented at the 14th International Conference" Romanian rural tourism in the context of sustainable development: present and prospects", Vatra Dornei, Romania, 25-26 May 2012.

5. Hitchcock, M., King, V.T., \& Parnwell, M. (2009). Introduction: ‘Tourism in Southeast Asia' revisited. In M. Hitchcock, V. T. King \& M. Parnwell (Eds.), Tourism in Southeast Asia: Challenges and new directions (pp. 1-42). Copenhagen, Denmark: NIAS Press.

6. Kim, H.J. \& Chen, M.H. (2006). Tourism Expansion and Economic Development: The Case of Taiwan. Tourism Management, 27, 925-933.

7. Massidda, C. \& Etzo, I. (2012) The Determinants of Italian Domestic Tourism: A Panel Data Analysis. Tourism Management, 33, 603-610.

8. Oh, C. O. (2005). The Contribution of Tourism Development to Economic Growth in the Korean Economy. Tourism Management, 26, 39-44.

9. Qian, J., Shen, H. \& Law, R. (2018). Research in Sustainable Tourism: A Longitudinal Study of Articles between 2008 and 2017. Sustainability, 10(590), 1-13.

10. Robaina-Alves, M., Moutinho, V., \& Costa, R. (2016). Change in energy-related CO2 (carbon dioxide) emissions in Portuguese tourism: a decomposition analysis from 2000 to 2008. Journal of Cleaner Production, $111,520-528$.

11. Shahzad, S.J.H., Shahbaz, M., Ferrer, R., \& Kumar, R.R. (2017). Tourismled growth hypothesis in the top ten tourist destinations: New evidence using the quantile-on-quantile approach. Tourism Management, 60, 223-232.

Analysing economic contribution of tourism: insights from selected Southeast Asian 
12. WEF (2017). https://www.weforum.org/reports/the-global-competitivenessreport-2017-2018.

13. WTTC (2018). retrieved from https://tool.wttc.org accessed on $16^{\text {th }}$ February 2019.

14. https:// businessmirror.com.ph/2015/03/18/tourism-in-southeast-asiais-growing-fast/)

15. https:/ / www.weforum.org/agenda/2017/04/ south-east-asia-s-mosttourism-friendly-destinations/. 